\title{
Incorporation of silverside meal to enhance diet palatability, growth performance and body composition of fingerlings sole Solea aegyptiaca (Chabanaud, 1927)
}

\author{
Abdel Moneim, M. Yones and Ataallah, A. Metwalli \\ National Institute of Oceanography \& Fisheries, Shakshouk Fish Research Station, \\ El-Fayoum, Egypt \\ E. mail: ata2010metwalli@hotmail.com - E. mail: yones_55200010@yahoo.com
}

\section{ABSTRACT}

The present study was conducted to determine the effects of use silverside meal to enhance palatability, growth performance and body composition of fingerlings sole fish fed on plant based diets. Two sources of plant protein (soybean and corn glutein meal) were replacing silverside meal in tested diets. Five diets were formulated with different inclusion levels of plant protein based diets (PP0, PP25, PP50, PP75 and PP100\%). The silverside fish (Atherina boyeri) was added to the diets as local animal protein source, replacer to fish meal and to enhance palatability of the test diets. Fingerlings sole with an initial weight of $(8.65 \pm 0.2 \mathrm{~g})$ were distributed 100 fingerlings in each tank, with a volume of $2 \mathrm{~m}^{3}$. Fish were fed on the artificial diets as $3 \%$ of the fish biomass daily divided into two equal portions. Fish were organized in triplicate groups/diet and the experimental period lasted 120 days after start. The results showed significant differences $(\mathrm{P}<0.05)$ in growth performance and feed efficiency between diets. The highest performances in terms of (Final weight, Weight gain, Average daily gain, Specific growth rate, Condition factor, Feed conversion ratio, Protein efficiency ratio, Net protein utilization and Hepatosomatic index) were obtained with the PP75, PP0, PP50 and PP25\%, without significance difference between them. However, fish fed on PP100 \% diet showed significant differences $(\mathrm{P}<0.05)$ with decreased growth performance and feed efficiency compared to the other tested diets. Non-significant differences $(\mathrm{P}<0.05)$ in the whole body chemical composition (dry matter, crude protein, crude lipid and ash) were found between fish fed on all experimental diets. The results of the present study indicated that PP75\% inclusion level, which reduce silverside meal and increase alternative plant protein sources in fingerlings sole, Solea aegyptiaca diet can be used without negative effects on growth performance and feed efficiency.

Keywords: Solea aegyptiaca, silverside fish, plant protein, inclusion level, growth performance.

\section{INTRODUCTION}

Salmonids, gilthead sea bream and sea bass play a lead role in European fish production. However, other farmed fish species are required to differentiate and widen the market supply. From emerging candidate species sengalese sole (Sole senegalensis) and common sole (Solea solea) show promise as stated farm early by Howell (1977) and more recently by Imsland et al., (2004). Common sole (Solea solea L.) is very promising candidate for European aquaculture, characterized by high flesh quality, high market value and a total production of $\sim 30$ tons per year (Howell et al., 2008). 
Thirty years ago, sole fish was already considered one of the most interesting and promising species for marine fish farming in Europe (Howell, 1977). The species however, never become a commercial success, due to technological and culture problem disease and the fact that this species requires warm water $\left(\sim 20 \mathrm{C}^{0}\right)$ for optimal growth in the juvenile and on-growing stages. This means that our culture area in Egypt is temperate and suitable for rearing sole. On the other hand, the advanced feed technology for weaning and on-growing stages are developed and led a renewed interest in sole as an aquaculture species (Howell, 1977, Dinis et al., 1999). The soles (Soleidae) assume to take a very important place in the Egyptian Mediterranean fisheries, where Egyptian sole (Solea aegyptiaca) is the most common species of soles that contributed about $6.5 \%$ of the total catch of trawl fishery, forming about $13 \%$ of the gross revenue of the trawling (Mehanna, 2007).

Kariman (2009) recorded that, catch composition of sole species during summer and winter seasons in Lake Qarun were more than 50 and 35\%, respectively. However, Eisawy and El-Bolock (1975) indicated that, S. vulgaris spawned and propagated successfully in Lake Qarun and it makes up about $36 \%$ of the total catch of Lake.

Hatchery production of sole spp. has been accomplished quiet easily and this has been a common bottleneck in the commercial production of other potential marine fish species. However, during the juvenile stages several factors combine to reduce the growth performance and thereby reduce the potential for commercial farming activities. These factors include feeding behavior, susceptibility to disease and stocking density (Imsland, 2004).

Studies on stomach contents of Solea sengaleses showed a dominance of polychaetes (Hediste diversicolor) but some amphipods and isopods were also identified (Bernardo,1990). The highest densities of sole were recorded in deep, warm, low salinity area with sediment of fine sand and high abundance of amphipods (Cabral and Costa, 1999). In Lake Qarun, S. aegyptiaca feeds mainly on macrobenthos (El-Shabrawy and Ahmed, 2007). The polychate Neries succinea seems to be the most preferred items species for sole, since it formed about 39.9 and $31.1 \%$ of its total food items during 1980 and 1995 (El-Shabrawy and Ahmed, 2007). Braber and de Groot (1973) mentioned that, the diet of Solea solea and S. vulgaris from Ebroestuary consisted mainly of polychaetes, crusraceans and molluscs. In contrast, the findings of the above authors (where polychaetes were the most important prey items of sole), crustaceans were the most important prey of S. solea in Bardawil lagoon (Sabrah, 2004).

Many studies during the 1970-1980 period demonstrated that, juvenile sole could be weaned from live food to formulated feeds and that success was dependent largely on the inclusion of either invertebrate tissues (Bromley,1977 and Metailler et al., 1981) and/or chemical taste attractants (Metailler et al., 1983).

The effect of chemical stimuli on the feeding of larval sole has been investigated by Knutsen (1992), who found that in sole larvae, the most potent substances were L-phenylalanine, L-lysine, L-aspragine, inosine-5-monophosphate and butane as feed attractant. The results of the same author show that, feeding of sole larvae is influenced by chemosensory processes at the early larval stage and that chemoreception may be an integrated part of sole feeding strategy. Cadena-Roa et al. (1982) investigated the use of attractive substances in feed to increase the feed intake of sole during weaning. They used extruded pellets because these are soft, palatable, resistant to leaching and can be sized. During a 45 days experiment, extruded pellets containing only water, oils and vitamins were compared with pellets mixed with the 
following additives: ground mollusks, ground artemia, ground polychaetes, mixture of glycine, L-alanine, L-glutamic acid, L-arginine, butane and inosine. They gave a better growth and survival than the control. Day et al. (1997) found that the survival of sole during weaning period was positively correlated to the level of hydrolyzed fish protein concentrate.

Focusing on the nutrition and feeding of common sole juveniles and ongrowing, which seem to be particularly critical points, some significant steps forward have recently been achieved to establish the optimal protein and lipid level for growth of seneglalensis (Borges et al., 2009). Other recent findings on juveniles of $S$. senegalensis (Silva et al., 2009) demonstrated the ability of sole spp. to grow equally well, when fed diets containing vegetable proteins as a partial substitution of fish meal. Less information is currently available for common sole ( $S$. solea) nutrition (Piccolo et al., 2008). Recently information on nutritional needs of this flatfish juvenile stage has been attained and the protein requirement for good overall growth performance has been estimated to be 50-60\% (Rema et al., 2008 and Yones \& Abdel-Hakim, 2011).

Due to its high nutritional value and palatability fish meal still remains the major dietary protein source comprising 20-60\% of fish feeds (Tacon, 1995). But supplies of fish meal and oil are limit and the choice of ingredients from available plant sources in aquafeed formulations is mainly driven by the price of fish meal and oil relative to those alternative ingredients. Increasing inclusion of plant proteins in aquafeeds is still a challenge for the sector due to insufficient information on the bioavailability of essential nutrients needed to formulate alternative feeds for major farmed species (Hardy, 2010). However, great research efforts have been devoted to the evaluation of various plant protein ingredients as sustainable alternatives in fish feeds is presently a major trend in aquaculture (Hardy, 2010 and Tacon \& Metian, 2008).

Replacement of fish meal by plant protein sources has been accomplished in a number of species at different levels (50-95\%) with a minimum amino acids supplementation, without jeopardizing growth performance, feed utilization and protein accretion (Dais et al., 2009; Kaushik et al., 2004).

The capacity of senegalese sole to cope with diets in which the marine-derived protein which replaced by plant protein ingredients was recently demonstrated (Dias et al., 2009; Silva et al., 2010; Valente et al., 2011) and it was further evidenced that, sole juveniles can grow equally well on diets completely devoid of fish meal provided the dietary AA were balanced (Silva et al., 2009).

Total replacement of live-feed is still far to happen but the possibility of an early weaning of larvae using micro-diets (MDs) could represent a valuable strategy to improve performance and reduce live feed utilization. First-time feeding fish larvae typically have a rudimentary digestive system characterized by a non-functional stomach and low digestive enzymes activity which make it difficult for them to process and assimilate a complex MDs (Kaushik, 2004). During the last decades, the utilization of a co-feeding regimen which gradually weans larvae of live preys has been able to promote digestive maturation at early age (Engrola et al., 2007, 2009).

Appelbaum (1985) concluded that, a certain proportion of a population of sole can be reared from eggs to juvenile fishes fed only a formulated diet. Day et al. (1997) using a commercial larval feed for weaning sole and recorded a growth rates comparable to those found for groups fed on live foods. Coutteau et al. (2001) evaluated the potential of formulated feed developed specifically fore sole and compared it with a commercial turbot feed for on-growing S. senegalensis. They 
reported that, the optimum diet for sole was a sinking extruded particle with a crude protein to crude fat ratio of 55/16 and a mixture of selected attractants to enhance attractability.

The present study aims to evaluate the use of silverside meal to enhance the palatability of different inclusion levels of plant protein based diets and its effects on growth performance and body composition of fingerlings sole Solea aegyptiaca reared in cement tanks.

\section{MATERIALS AND METHODS}

\section{Fish culture and experimental diets}

The present study was conducted using the research facilities of the experimental station at Shakshouk, Fayoum Governorate, National Institute of Oceanography and Fisheries (NIOF). The system contained two water pumps and two upstream sandy filter units at a point between the water source and tanks. Each pump was drowning the water from Lake Qarun to the storage tanks and forced it to the rearing tanks in open system. Physicochemical characteristics of water tanks were examined every two weeks according to APHA (1992).

Fingerlings Solea aegyptiaca were caught from Lake Qarun and transferred to the laboratory of the station. Artemia nauplii were obtained from Emisal Company in Shakshouk and used as live feeds in the first days, then it was gradually replaced by the experimental diets within two weeks of acclimatization period. Fingerlings solea with an average initial weight of $8.65 \pm 0.2 \mathrm{~g}$ were randomly distributed and stocked at 100 fingerlings/ tank in 15 circular cement tanks with a volume of $\left(2 \mathrm{~m}^{3}\right)$ each representing five diets in triplicates. The cement tanks were provided by sand layer of $10 \mathrm{~cm}$ in the bottom.

Five diets were formulated in order to replace silverside meal partially and totally by mixture of soybean and gluten meal as plant protein based diets representing five diets as (PP0, PP25, PP50, PP75 and PP 100\%, respectively). The formulation and chemical composition analysis of diets are presented in (Table 1). Silverside fish (Atherina boyeri) were obtained from local market in Shakshouk, then dried and ground to use it in feed formulation as a local ingredient to replace imported fish meal and enhance diet palatability. All diets were processed into dry sinking pelleted form, using California pelleting machine with $2 \mathrm{~mm}$ diameter. The experimental diets were fed at $3 \%$ of live body weight (BW), twice daily at 10.00 a.m and 16.00 p.m. The experimental treatments were triplicated and lasted 120 days after start.

\section{Chemical analysis}

The silverside fish used in feed formulation, the experimental diets and fish carcass were dried for subsequent protein (Kieldahl), ether extract (Soxhlet) and moisture analysis were determined according to AOAC (2006) methods. Protein levels were calculated by multiplying the total nitrogen $(\mathrm{N})$ with 6.25 . Nitrogen free extract was estimated based on the difference between the dry matter content minus protein, fat and ash content according to AOAC (2006). Amino acid composition of silverside fish was determined by High Performance Liquid Chromatography (HPLC), following acid-hydrolysis of samples. For amino acids analysis, silverside fish was hydrolyzed with $6 \mathrm{NHCl}$ at $110^{\circ} \mathrm{c}$ for $24 \mathrm{~h}$ for the chromatographic separation using the HPLC as described by Gardner and Miller (1980). Tryptophan was determined calorimetrically in alkaline hydrolysate according to the method described by Blauth et al. (1963). 
Table 1: Formulation and chemical composition of the experimental diets.

\begin{tabular}{|c|c|c|c|c|c|}
\hline \multirow[t]{2}{*}{ Ingredientes } & \multicolumn{5}{|c|}{ Diets } \\
\hline & PP0 & PP25 & PP50 & PP75 & PP100 \\
\hline Silverside meal & 40 & 30 & 20 & 10 & - \\
\hline Poultry-by-product meal & 35 & 35 & 38 & 50 & 69 \\
\hline Soybean meal & - & 13 & 26 & 29 & 22.5 \\
\hline Corn gluten meal & - & 5 & 5 & 2.8 & 1 \\
\hline Wheat bran & 18 & 10 & 4 & 1 & - \\
\hline Fish oil & 3 & 3 & 3 & 3 & 3 \\
\hline Sunflower oil & 3 & 3 & 3 & 3 & 3 \\
\hline Vitamin/ Mineral Mix ${ }^{1}$ & 1 & 1 & 1 & 1 & 1 \\
\hline L-Lysine & - & - & - & 0.1 & 0.3 \\
\hline DL-Methionine & - & - & - & 0.1 & 0.2 \\
\hline Total & 100 & 100 & 100 & 100 & 100 \\
\hline \multicolumn{6}{|l|}{ Chemical composition (\%Dry matter $)$} \\
\hline Dry matter & 92.8 & 92.4 & 92.6 & 92.8 & 92.2 \\
\hline Crude protein & 50.12 & 50.04 & 50.12 & 50.07 & 50.04 \\
\hline Ether extract & 16.47 & 15.51 & 14.93 & 15.53 & 17.04 \\
\hline Nitrogen free extract & 15.17 & 16.75 & 16.92 & 16.26 & 14.16 \\
\hline Fiber & 2.43 & 3.01 & 3.74 & 3.92 & 3,62 \\
\hline Ash & 15.81 & 14.69 & 14.29 & 14.22 & 15.14 \\
\hline Gross energy $\mathrm{MJ} \mathrm{kg}^{-1} \operatorname{diets}^{2}$ & 21.18 & 21.09 & 20.88 & 20.88 & 21.22 \\
\hline Metabolizable energy $\mathrm{MJ} \mathrm{kg}^{-1} \mathrm{diet}^{3}$ & 17.56 & 17.26 & 17.28 & 17.19 & 17.61 \\
\hline
\end{tabular}

1-Vitamin-mineral premix, (mg or $\mathrm{g} \mathrm{Kg}^{-1}$ dry diets); vitamine $\mathrm{B} 12,0.1 \mathrm{mg}$; vitamne $\mathrm{k}, 10 \mathrm{mg}$; inositol, $800 \mathrm{mg}$, pantochenic acid, $60 \mathrm{mg}$; niacin acid,200mg; thiamin, 20mg; riboflavin, $40 \mathrm{mg}$; pyridoxine HCL,20mg; folic acid,29mg; biotin, $120 \mathrm{mg}$; retinol acetate, $32 \mathrm{mg}$; cholecalciferol, $5 \mathrm{mg}$ $\square$-tocopheryl-acetate, $120 \mathrm{mg}$; ascorbic acid, $2000 \mathrm{mg}$; choline chloride, $2500 \mathrm{mg}$; ethoxyquin, 150mg, KH2PO4, 22mg; FeSO47H2O, 1mg;ZnSO47H2O,0.13mg; MnSO44H2O, 52.8mg; $\mathrm{CuSO} 45 \mathrm{H} 2 \mathrm{O}, 12 \mathrm{mg} ; \mathrm{Ki}, 2 \mathrm{mg}$.

2-Lozano et al. (2007).

3-Jobling (1994).

Fatty acids, total lipids were extracted according to Folech et al. (1957). Fatty acid methyl esters were prepared by acid-catalyzed transmethylation of total lipids (Shantha \& Ackman, 1990). They were analyzed in a Varian 3400 gas chromatograph, equipped with a wax fused capillary column (30 mx $0.25 \mathrm{~mm}$ i.d, film thickness, $0.25 \mathrm{Mm}$, Jw, USA), using helium as carrier gas $(1.2 \mathrm{ml} / \mathrm{min})$ and thermal gradient from 180 to $240^{\circ} \mathrm{C} / \mathrm{min}$. injector and flam ionization detector temperature were 260 and $250^{\circ} \mathrm{C}$, respectively. Data were recorded on spectra physics 4270 integrator. Identification of individual fatty acid was made by comparison with known standard mixture.

Gross energy ( $\mathrm{MJ} \mathrm{Kg}^{-1}$ diet) was calculated according to Lozano et al. (2007) using the following calorific values: $23.9,39.8$ and $17.6 \mathrm{MJ} \mathrm{g}^{-1}$ diet for protein, ether extract and nitrogen free extract, respectively. The metabolizable energy contents of the experimental diets were calculated as 18.9, 35.7 and $14.7 \mathrm{MJ} \mathrm{g}^{-1}$ diet for protein, lipid and nitrogen free extract, respectively according to Jobling (1994).

\section{Statistical analysis}

One way Analysis of Variance (ANOVA) was applied to test the effect of different dietary inclusion levels of plant protein based diets on various growth parameters, nutrient utilization and chemical composition of experimental fish according to Snedecore \& Cochran (1987). Duncan Multiple Range test was used to detect the significant differences between the means of treatments (Duncan, 1955). All analysis was performed using SAS (version 6, 1986 SAS Institute, Cary, NC, USA). 


\section{RESULTS}

\section{Physicochemical characteristics}

Water physicochemical characteristics (Table 2) revealed that, temperature, $\mathrm{pH}$, dissolved oxygen, salinity and unionized ammonia are within the optimum ranges for rearing sole according to Fonds (1976). Similar physicochemical conditions were observed in all tanks.

Table 2: Average of water physicochemical characteristic parameters during the experimental period (Mean \pm S.E.).

\begin{tabular}{|c|c|c|c|c|c|}
\hline \multirow[t]{2}{*}{ Parameters } & \multicolumn{5}{|c|}{ Diets } \\
\hline & PP0 & PP25 & PP50 & PP75 & PP100 \\
\hline Temperature $\mathrm{C}^{\mathrm{o}}$ & $25.0 \pm 0.21$ & $25.1 \pm 0.20$ & $25.2 \pm 0.24$ & $25.4 \pm 0.21$ & $25.3 \pm 0.22$ \\
\hline $\mathrm{pH}$ & $7.5 \pm 0.12$ & $7.4 \pm 0.11$ & $7.4 \pm 0.13$ & $7.5 \pm 0.11$ & $7.4 \pm 0.12$ \\
\hline Dissolved oxygen $(\mathrm{mg} / \mathrm{l})$ & $6.5 \pm 0.11$ & $6.4 \pm 0.14$ & $6.3 \pm 0.16$ & $6.4 \pm 0.11$ & $6.5 \pm 0.14$ \\
\hline Salinity \%o & $35.13 \pm 0.11$ & $35.14 \pm 0.15$ & $35.12 \pm 0.13$ & $35.12 \pm 0.13$ & $35.12 \pm 0.11$ \\
\hline Unionized ammonia (mg/l) & $0.021 \pm 0.01$ & $0.022 \pm 0.001$ & $0.020 \pm 0.001$ & $0.021 \pm 0.001$ & $0.021 \pm 0.001$ \\
\hline
\end{tabular}

\section{Chemical composition of silverside (Atherina boyeri) and diets Protein, Amino acids and Fatty acids}

As presented in (Table 1), the experimental diets were similar in their protein and energy contents, but differently in plant protein inclusion levels. Results of the chemical composition of Atherina boyeri are shown in (Table 3). They showed a high protein (19.8\% $\mathrm{w} / \mathrm{w}$ basis), moderate lipid $(6.8 \% \mathrm{w} / \mathrm{w}$ basis) and low ash contents $(2.6 \% \mathrm{w} / \mathrm{w}$ basis $)$. Results in (Table 4) revealed that, the highest value of amino acids were detected for glutimic acid $(8.6 \%)$ followed by aspartic acid (7.5\%). Table (4) also cleared that, all essential amino acids in silverside fish were almost of the same profile of the commercial imported fish meal in the Egyptian market except that a slight increase in arginene as an essential amino acids and high value of glutimic compared with silverside fish, where silverside fish is higher in theronine as essential amino acid compared to commercial fish meal. As shown in (Table 5), saturated fatty acids (SFA) in Atherina boyeri constitute the majority of the fatty acids pool, followed by monounsaturated (MUFA) and polyunsaturated (PUFA) fatty acids, respectively.

Table 3: Chemical composition of the whole body of Atherina boyeri, caught from Lake Qarun (\% w/w basis).

\begin{tabular}{lclc}
\hline \multicolumn{1}{c}{ Parameters } & (\%w/w basis) & Parameters & (\%w/w basis) \\
\hline Dry matter & $29.2 \pm 1.2$ & Lipid & $6.8 \pm 0.22$ \\
Protein & $19.8 \pm 0.43$ & Ash & $2.6 \pm 0.16$ \\
\hline
\end{tabular}

Table 4: Amino acids composition (g/100g crude protein) of silverside, Atherina boyeri caught from Lake Qarun and commercial fish meal ( $\mathrm{M} \pm \mathrm{S}$.E.).

\begin{tabular}{lcclcc}
\hline $\begin{array}{c}\text { Amino acids(g/100g } \\
\text { crude protein) }\end{array}$ & Silverside & Fish meal* & $\begin{array}{c}\text { Amino acids }(\mathrm{g} / 100 \mathrm{~g} \\
\text { crude protein) }\end{array}$ & Silverside & Fish meal* \\
\hline Arginine & $5.4 \pm 0.24$ & 6.4 & Tyrosine & $2.5 \pm 0.11$ & 2.6 \\
Histidine & $1.9 \pm 0.11$ & 2 & Threonine & $6.2 \pm 0.41$ & 3.9 \\
Isolucine & $4.2 \pm 0.43$ & 3.7 & Trptyophane & $1.4 \pm 0.12$ & 0.9 \\
Leucine & $6.1 \pm 0.66$ & 6.5 & Valine & $4.4 \pm 0.22$ & 4.5 \\
Lysine & $6.6 \pm 0.44$ & 6.9 & Alanine & $5.5 \pm 0.35$ & 6.3 \\
Methionine & $2.8 \pm 0.16$ & 2.6 & Glutimic acid & $8.6 \pm 0.88$ & 12.8 \\
Cystine & $0.8 \pm 0.1$ & 0.9 & Aspartic acid & $7.5 \pm 0.45$ & 8.5 \\
Phenylalanine & $3.2 \pm 0.33$ & 3.3 & Serine & $4.4 \pm 0.34$ & 4.8 \\
\hline
\end{tabular}


Table 5: Fatty acids composition (\% of total fatty acids) of silverside, Atherina boyeri caught from Lake Qarun (M \pm S.E.).

\begin{tabular}{lclllc}
\hline Fatty acid & $\%$ & Fatty acid & $\%$ & Fatty acid & $\%$ \\
\hline C14: 0 & $6.4 \pm 0.21$ & C16:2n-4 & $0.91 \pm 0.11$ & C22:6n-3 & $7.44 \pm 0.48$ \\
C16:0 & $28.5 \pm 1.4$ & C16:3n-4 & $0.94 \pm 0.12$ & SFA & $40.16 \pm 1.8$ \\
C18:0 & $5.26 \pm 0.41$ & C18:2n-6 & $4.38 \pm 0.45$ & MUFA & $23.96 \pm 1.2$ \\
C16: $1 \mathrm{n}-7$ & $6.5 \pm 0.32$ & C18:4n-3 & $1.62 \pm 0.14$ & PUFA & $23.68 \pm 1.4$ \\
C18:1n-9 & $13.14 \pm 0.67$ & C20:4n-6 & $1.45 \pm 0.12$ & $\Sigma-n-3$ & $16.0 \pm 1.1$ \\
C18:1n-7 & $1.7 \pm 0.11$ & C20:5n-3 & $6.16 \pm 0.45$ & $\Sigma-n-6$ & $5.83 \pm 0.45$ \\
C20:1n-9 & $2.62 \pm 0.14$ & C22:5n-3 & $0.78 \pm 0.13$ & n-3/n-6 & $0.36 \pm 0.24$ \\
\hline
\end{tabular}

\section{Growth performance}

As presented in (Table 6), averages of initial weights ranged between 8.4 to 8.8 $\mathrm{g} /$ fish with insignificant differences among the dietary groups indicating the random distribution of the experimental fish among treatment groups. Concerning growth performance parameters (Table 6) the highest final weights of sole fish $(\mathrm{P}<0.05)$ were recorded by PP75,PP0, PP50 and PP25\% groups followed in a significant decreasing order by PP100\%. The same trend was observed with total gain, daily gain and specific growth rate, where PP75\%,PP0,PP50 and PP25\% groups recorded the highest values followed in a significant $(\mathrm{P}<0.05)$ decreasing order by $\mathrm{PP} 100 \%$. It was also observed that, groups PP75 and PP0 recorded significantly $(\mathrm{P}<0.05)$ higher values of condition factor compared to $\mathrm{PP} 100 \%$ group, indicating that the two former groups (PP75 and PP0) grow better in weight than in length. In addition results of survival rate were $99 \%$ for all dietary treatments groups indicating that, the tested diets had no effects on sole fish survival rates, thus all mortalities were due to accidental factors during recording the fish weight every two weeks to adjust the feed amounts.

As can be seen in (Table 6), average amounts of feed consumed were found to be 45.0, 44.0, 43.0,42 and 40.0g for fish fed PP100,PP50,PP75,PP25and PP50, respectively, indicate slight increases in feed consumption with fish fed $100 \%$ plant protein based diet. On the other hand, the best FCR (lowest) values were obtained by the PP0,PP75,PP50 and PP25\% groups, respectively, followed in an significant $(\mathrm{P}<0.05)$ increasing order (worth) by PP100\% inclusion level. As presented in the same Table, the highest PER values (1.8) were recorded by each PP0 and PP75\% groups followed in an insignificance decreasing order by PP25 and PP50\% groups and significance value with PP100\% diet. Concerning the NPU\% values, the groups of PP0 and PP75\% recorded the highest $(\mathrm{P}<0.05)$ values as compared to the other groups. However, insignificant differences were found for the hepatosomatic index (HSI) among dietary treatments.

\section{Carcass analysis}

Proximate composition of whole fish body analysis did not change significantly in terms of dry matter, crude protein, crude lipid and ash contents by different dietary treatments (Table 7). However, the whole fish body lipid was slightly decreased by the increasing dietary plant protein inclusion levels in the diets without significant differences $(\mathrm{P}<0.05)$ between the dietary treatments. 
Table 6: Growth performance mean values of Solea aegyptiaca fed on the experimental diets (Mean \pm S.E.).

\begin{tabular}{|c|c|c|c|c|c|}
\hline \multirow[t]{2}{*}{ Parameters } & \multicolumn{5}{|c|}{ Diets } \\
\hline & PP0 & PP25 & PP50 & PP75 & PP100 \\
\hline Initial aveg. weight (g/fish) & $8.6 \pm 0.2$ & $8.4 \pm 024$ & $8.5 \pm 0.22$ & $8.7 \pm 0.21$ & $8.8 \pm 0.2$ \\
\hline Final aveg. weight (g/fish) & $45.5 \pm 1.6^{\mathrm{a}}$ & $44.5 \pm 1.8^{\mathrm{a}}$ & $45.0 \pm 1.4^{\mathrm{a}}$ & $47.5 \pm 1.5^{\mathrm{a}}$ & $41.5 \pm 1.4^{\mathrm{b}}$ \\
\hline Total gain (g/fish) & $36.9 \pm 1.2^{\mathrm{a}}$ & $36.1 \pm 1.4^{\mathrm{a}}$ & $36.6 \pm 1.6^{\mathrm{a}}$ & $38.8 \pm 1.1^{\mathrm{a}}$ & $32.7 \pm 1.6^{\mathrm{b}}$ \\
\hline Average daily gain (g/fish/day) & $0.3 \pm 0.1^{\mathrm{a}}$ & $0.3 \pm 0.12^{\mathrm{a}}$ & $0.3 \pm 0.1^{\mathrm{a}}$ & $0.32 \pm 012^{\mathrm{a}}$ & $0.27 \pm 0.1^{\mathrm{b}}$ \\
\hline Specific growth rate ${ }^{1}$ & $1.38 \pm 0.22^{\mathrm{a}}$ & $1.39 \pm 0.24^{\mathrm{a}}$ & $1.38 \pm 0.21^{\mathrm{a}}$ & $1.41 \pm 0.24^{\mathrm{a}}$ & $1.29 \pm 0.18^{b}$ \\
\hline Condition factor $\left(\mathrm{g} / \mathrm{cm}^{-3}\right)^{2}$ & $1.36 \pm 0.24^{\mathrm{a}}$ & $1.34 \pm 0.22^{\mathrm{a}}$ & $1.35 \pm 0.21^{\mathrm{a}}$ & $1.37 \pm 0.21^{\mathrm{a}}$ & $1.3 \pm 0.22^{b}$ \\
\hline Survival rate $\%$ & 99 & 99 & 99 & 99 & 99 \\
\hline Feed consumed (g/ fish)* & 40.0 & 42.0 & 44.0 & 43.0 & 45.0 \\
\hline Feed conversion ratio ${ }^{3}$ & $1.08 \pm 0.12^{\mathrm{a}}$ & $1.16 \pm 0.18^{\mathrm{a}}$ & $1.2 \pm 0.14^{\mathrm{a}}$ & $1.1 \pm 0.16^{\mathrm{a}}$ & $1.37 \pm 0.12^{b}$ \\
\hline Protein efficiency ratio ${ }^{4}$ & $1.8 \pm 0.15^{\mathrm{a}}$ & $1.71 \pm 0.16^{\mathrm{a}}$ & $1.65 \pm 0.14^{\mathrm{a}}$ & $1.8 \pm 0.18^{\mathrm{a}}$ & $1.45 \pm 0.12^{b}$ \\
\hline Net protein utilization 5 & $35.77 \pm 1.8^{\mathrm{a}}$ & $33.6 \pm 1.4^{\mathrm{a}}$ & $32.38 \pm 1.8^{\mathrm{a}}$ & $34.78 \pm 1.5^{\mathrm{a}}$ & $28.2 \pm 1.4^{\mathrm{b}}$ \\
\hline $\operatorname{HSI}(\%)^{6}$ & $1.16 \pm 0.2^{\mathrm{a}}$ & $1.14 \pm 0.1^{\mathrm{a}}$ & $1.15 \pm 0.21^{\mathrm{a}}$ & $1.16 \pm 0.2^{\mathrm{a}}$ & $1,13 \pm 014^{\mathrm{a}}$ \\
\hline
\end{tabular}

Means in the same row with different superscript letters are significantly different $(\mathrm{P}<0.05)$.

$*$ Non-consumed portion of food was collected, dried and deducted from total given ration.

1 -Specific growth rate $=100 \times($ Ln final weight-Ln initial weight $) / 120$ days (experimental period $)$.

2- Condition factor $(\mathrm{g} / \mathrm{cm}-3)=($ wet weight $) /($ total length-3 $) \times 100$.

3- Feed conversion ratio $(\mathrm{FCR})=($ feed given per fish $) /$ (weight gain per fish).

4- Protein efficiency ratio $(\mathrm{PER})=($ weight gain per fish $) /$ (protein intake per fish).

5 -Net Protein utilization $($ NPU\% $)=($ Final body protein-initial body protein/protein intake $) \times 100$.

6-Hepatosomatic index $($ HSI \%) $=$ (liver weight $) /($ fish weight $) \times 100$.

Table 7: Whole body composition analysis of Solea aegyptiaca (Mean \pm S.E.) fed on the experimental diets $(\% \mathrm{w} / \mathrm{w}$ basis $)$.

\begin{tabular}{lcccccc}
\hline \multirow{1}{*}{ Items } & \multicolumn{7}{c}{ Diets } \\
\cline { 2 - 6 } & Initial & PP0 & PP25 & PP50 & PP75 & PP100 \\
\cline { 2 - 6 } Dry matter & $29.0 \pm 1.6$ & $29.2 \pm 1.4^{\mathrm{a}}$ & $29.3 \pm 1.8^{\mathrm{a}}$ & $29.7 \pm 1.5^{\mathrm{a}}$ & $29.2 \pm 1.4^{\mathrm{a}}$ & $29.4 \pm 1.5^{\mathrm{a}}$ \\
Protein & $19.8 \pm 1.2$ & $19.5 \pm 1.4^{\mathrm{a}}$ & $19.6 \pm 1.2^{\mathrm{a}}$ & $19.5 \pm 1 .^{2 \mathrm{a}}$ & $19.4 \pm 1.4^{\mathrm{a}}$ & $19.5 \pm 1.2^{\mathrm{a}}$ \\
Lipid & $5.0 \pm 0.4$ & $5.4 \pm 0.5^{\mathrm{a}}$ & $5.1 \pm 0.3^{\mathrm{a}}$ & $5.2 \pm 0.4^{\mathrm{a}}$ & $5.0 \pm 0.5^{\mathrm{a}}$ & $5.2 \pm 0.2^{\mathrm{a}}$ \\
Ash & $4.2 \pm 0.22$ & $4.3 \pm 0.4^{\mathrm{a}}$ & $4.6 \pm 25^{\mathrm{a}}$ & $5.0 \pm 0.35^{\mathrm{a}}$ & $4.8 \pm 0.26^{\mathrm{a}}$ & $4.7 \pm 0.36^{\mathrm{a}}$ \\
\hline
\end{tabular}

Means in the same raw with different super script letters are significantly different $(\mathrm{P}<0.05)$.

\section{DISCUSSION}

In the laced decide many research effort have been conducted towards the use of plant protein ingredients as alternative sources to replace fish meal. The suitability of this replacement in terms of growth performance and feed efficiency is highly variable among fish species and experiential conditions. Recent research showed that, a sensible blend of different plant protein sources is reasonable to balance the indispensable amino acids profile, and hence minimizing the required amino acid supplementation to the diet (Schulz et al., 2007; Dais et al., 2009; Silva et al., 2009).

The proximate composition of silverside (Atherina boyeri) meal from protein, amino acids and fatty acids showed that, it is good nutrient that could be utilized by sole. The high protein contents and moderate lipid levels in (Atherina boyeri) are similar to that found in the same species by (Bouriga et al., 2010; Yones \& AbdelHakim, 2011) and other species such as Sardine (Bandarra et al., 2001) and Sarda (Zaboukas et al., 2006). The highest concentration of both glutamic acid and threonine are in agreement with previous studies (Adeyeye, 2009; Bouriga et al., 2010; Selmi et al., 2010; Yones and Abdel-Hakim, 2011). The high proportion of n-3 PUFA was found in this study are in agreement with the other results recorded by (Osman et al., 2001; Passi et al., 2002; Bouriga et al., 2010; Yones \& Abdel-Hakim, 2011). The experimental diets used during the present study were formulated to have 
similar protein and energy levels. The diets were prepared to cover the optimum requirements of this species as recorded by (Yones \& Abdel-Hakim, 2011). The diets also confirmed the feasibility of using silverside meal in the feed formulation of sole due to less cost and palatability to this species.

The results of the current study showed that plant protein based diet can be used up to $75 \%$ without exerting any deleterious effect on growth performance and feed efficiency of juvenile sole, meaning the reduction of silverside fish from $40 \%$ to $10 \%$ by replacing with a blend of plant protein sources. The combination of adequate plant protein sources together with the inclusion of palatability-enhancing feed ingredients as silverside fish meal in the present study are similar with the added of squid meal or fish protein hydrolysate in juvenile sengegalese sole (Silva et al., 2010). In several fish species total fish meal replacement has been achieved with some success (Kaushik et al., 2004; Espe et al., 2006). Sole in the present study showed well accept of plant ingredients and these results are in agreements with the previous research in sole (Silva et al., 2010; Cabral et al., 2011; Valente et al., 2011).

The present study indicated that, the growth performance parameters (final weight, daily gain, specific growth rate and condition factor) recorded an increase with PP75\% inclusion level. The similar results were reported with Bonaldo et al., (2006) in juvenile Egyption Sole (Solea aegyptiaca), singalese sole fed plant protein based diet (Cabral et al., 2011) and animal protein based diets (Borges et al., 2009 and Yones \& Abdel-Hakim, 2011). The present results also show that the total replacement of silverside fish by plant protein based diet (PP100\%) had a significant impact in the growth performance. The same finding was reported in sole (Cabral et al., 2011) and trout (Burr et al., 2012). On the other hand, Valente et al., 2011, mentioned that, total replacement of fish meal by plant protein based diet had no major impact on growth performance of market size senegalse sole. These data suggest a great potential for plant ingredients to replace fish meal as a dietary protein source for sole, supplemented with unbalanced amino acid as recorded by (Silva et al., 2009, 2010). In the same trend, total replacement of fish meal by PP was successfully accomplished in European sea bass (Kaushik et al.,2004) and Atlantic salmon, Salmo salar L., (Espe et al., 2006) without compromising growth or protein utilization. The conflicting results among studies are probably related to the genetic origin, size and experimental condition.

Adequate feed intake is a precondition to guarantee a precise nutritional evaluation of plant proteins in fish feed. A feed intake reduction has been observed when including high level of plant protein concentration in the diet of gilthead sea bream (Kissil et al., 2000). This may be related to the presence of detractive compounds in plant derived ingredients. The high feed intake among plant protein based diet may be due to the incorporation of silverside fish that improve diets palatability, as previously suggested with sole (Cabral et al., 2011) and other fish species (Espe et al., 2006 and Zhang et al., 2012) fed on plant protein based diet supplemented with palatable material such as squed meal and protein fish hydrolyised meal.

From the present data, it was observed a decrease in feed conversion ratio and increase in protein utilization (PER and NPU) with PP0 and PP75\% diets, these results reflected efficient utilization of the feed by sole juvenile. Similar values were recorded with all inclusion level except that PP100\% showed poorest value (1.37). The present results were also comparable with the previous values registered with sole juvenile (Silva et al., 2009, 2010; Cabral et al., 2011; Yones \& Abdel-Hakim, 2011). The HSI is often used as an indicator of condition and nutritional status of fish. The 
results of HIS in the present trial indicated that no negative influence of plant protein based diet were found when replaced fish meal, confirming previous results on juvenile sole (Silva et al., 2009, 2010; Cabral et al., 2011).

Solea aegyptiaca is considered a lean fish having 5\% lipid in whole body composition (Yones \& Abdel-Hakim, 2011). The present results of whole body composition between different treatments not affected by pp inclusion level. Such values are within the range of those previously recorded in sole (Silva et al., 2009, 2010; Cabral et al., 2011).

In conclusion, replacement of dietary silverside meal protein by a blend of plant protein sources up to $75 \%$ did not adversely affect growth performance, nutrient utilization and proximate composition of fingerlings Solea aegyptiaca. Our results confirm the feasibility of using silverside meal in the feed formulation as alternative and cheap protein source to fish meal in feeding sole, due to less cost and enhancing palatability of this species. Further studies on plant protein type and digestibility could still be effective to help selecting the adequate plant protein combination for this species.

\section{REFERENCES}

Adeyeye, E.L. (2009). Amino acid composition of three species of Nigerian fish, Clarias anguillaris, Oreochromis niloticus and Cynoglossus senegalensis. Food Chem., 113:43-46.

AOAC 2006. Official methods of analysis of AOAC International. 18 ed. AOAC International Maryland, USA.

APHA (1992). Standard methods for the examination of water and waste water. American Public Health Association, Washington, DC, 1134pp.

Appelbaum, S. (1985). Rearing of Dover sole, Solea solea L. throught its larval stage using artifical diets. Aquacult., 49: 209-221.

Bandarra, N.M.; Batista,I.; Nunes, ML and Empis,J.M. (2001). Seasonal variation in the chemical composition of Horse Mackerel (Trachurus trachurus). Eur. Food Res. Technol., 212: 535-539.

Bernardo, J. (1990). Dinamica de una lagoa Costeria eutrofica (lagoa di Santo andre) Ph.D. Thesis, Faculdade de Ciencias universidade de Lisboa, Portugal.

Blauth, D.J.; Chareinski,M. and Drelic, H. (1963). A new rapid method for determining tryptophan. Anal. Chem., 96-99.

Bonaldo, A.; Roen, A.J.; Pecchini, A.; Grill, E. and Gatta, P.P. (2006). Influnce of dietary soybean meal levels on growth, feed utilization and gut histology of Egyption Sole (Solea aegyptiaca) juvenile. Aquacult., 261:580-586.

Borges, P.; Oliveira, B.; Casal, S.; Dias, J.; Coneicao, L. and Valente, L.M.P. (2009). Dietary lipid level affect growth performance and nutrient utilization of Senegalse sole (Solea seneggalensis) juveniles. The Brit. J. of Nutri. 102: 1007-1014.

Bouriga, N.; Selmi, S.; Faure, E. and Trabelsi, M. (2010). Biochemical composition of three Tunisian silverside fish populations caught in open sea, lagoon and island coasts. Afri.J. of Biotechnol., 9 (26): 414-419.

Braber, L. and de Groot, S. J. (1973). The food of live flatfish species (Pleurone ctiforms) in the northern. North sea, Neth. J. Sea Res., 6: 163-172.

Bromley, P.J. (1977). Methods of weaning Juvenile hatchery reared Sole (Solea solea L.) from live food to prepared diets. Aquacult., 12: 337-347. 
Burr, G. S.; Wolters, W.R.; Barrows, F.T. and Hardy, R.W. (2012). Replacing fish meal with blends of alternative proteins on growth performance of rainbow trout (Oncohynchus mykiss), and early or late stage juvenile Atlantic salmon (Salmo salar). Aquacult., 334-337:110-116.

Cabral, H. and Costa, M. G. (1999). Differental use of nursery areas within the Tagus Estuary by sympatric soles Solea solea and Solea senegalensis. Environ. Biol. Fish., 56:389-397.

Cabral, E.M.; Bacelar, M., Batista,S.; Castro-Cunha,M. and Ozorio,R,O.A. (2011). Replacement of fish meal by increasing levels of plant protein blends in diets for Senegalese sole (Solea senegalese) juveniles. Aquacult., 322:74-81.

Cadena-Roa, M.; Huelvan, C.; Le Borgne, Y. and Metailler, R. (1982). Use of rehydrated extruded pellets and attractive substances for weaning of Sole (Solea vulgaris). J.World Maric. Soc., 13:246-253.

Coutteau, P.; Robles, R. and Spruyt, W. (2001). On-growing feed for Solea senegalensis Kaup, 1858. In abstract of contribution presented at the international conference, Aquaculture Europe 2001. Special publication no, 29. Euro. Aquacult. Soci. pp 58-59.

Dias, J.; Conceicao, L.E.C.; Ribeiro, A.R., Borges,P.; Valente, L.M.P.and Dinis, M. T. (2009). Practical diet with low fish-derived protein is able to sustain growth performance in gilthead sea bream (Sparus aurata) during the grow-out phase. Aquacult., 293:255-266.

Day, O.J.; Howell, B.R. and Jones, D.A. (1997). The effect of dietary hydrolysed fish protein concentrate on the survival and growth of Dover sole Solea solea (L) during and after weaning . Auacult. Res.,28:911-922.

Dinis, M. T.; Ribeiro, L.; Soares, F. and Sarastuele, C. (1999). A review on the cultivation potential of Solea senegalensis in Spain and Portugal. Aquacult., 176:27-38.

Duncan, D. B. (1955). Multiple ranges and multiple F. test. Biometric, 11: 1-42.

Eisawy, A. and El-Bolock, A. (1975). Status of aquaculture in the Arab Republic of Egypt. Symposium on aquaculture in Africa, Ghana, 30 Sept. -2 Octob., 1975.

El-Shabrawy, G. M. and Ahmed, K. N. (2007). Seasonal and long term changes of macrobenyhos in Lake Qarun. Egypt J.Acad. Soc. Environ. Develop., 8 (3):115.

Engrola, S.; Conceicao, L.E.C.; Dias, L.; Pereria, R.; Ribeiro, L. and Dinis, M. T. (2007). Improving weaning strategies for Senegalse sole: effects of body weight and digestive capacity. Aquacult., 38: 696-707.

Engrola, S.; Figueira, L.; Conceicao, L.E.C.; Cavaia, P.J. Ribeiro,L.; Dinis, M.T. (2009). Co-feeding in Senegalse sole larvae with inert diet from mouth opening promotes growth at weaning. Aquacult., 288: 264-272.

Espe, M.; Lemne,A.; Petri,A. and El-Mowafi, A. (2006). Can Atlantic salmon (Salmo salar) grow on diet devoid of fish meal?. Aquacult., 255: 255-262.

Folech, J.; Lees, M. and Sloane Stanley, G. (1957). A simple method for the isolation and purification of total lipids form animal tissues, J. Biol. Chem. 226: 497-509.

Fonds, M. (1976). The influence of temperature and salinity on growth of young sole Solea solea L. Eur. Symp. Mar. Biol., 1:109-125.

Gardner, W. S. and Miller, W. H. (1980). Reverse phase lipid chromatography of amino acids after reaction with opthaladehyde. Anal. Biochem., 101: 61-70.

Hardy, R. W. (2010). Utilization of plant proteins in fish diets: effects of global demand and supplies of fish meal. Aquacult. Res., 41:770-776. 
Howell, R.R. (1997). A re-approisal of the potential of the Sole Solea solea L. for commercial cultivation. Aquacult., 155: 359-369.

Howell, B.; Conceicao, L.; Prickett, R.; Cananos, P. and Mananos, E. (2008). Report of the $4^{\text {th }}$ workshop on the cultivation of sole. Center of Marine Sciences (CCMAR). University of the Alarve Faro.Portugal, $47 \mathrm{pp}$.

Imsland, A. K.; Fos, A.; Conceicao, L. E. C.; Dinis, M. T.; Delbar, D.; Schram, E.; Kamstra, A.; Rema, P. and White, P. (2004). A review of the culture potential of Solea solea and S. senegalensis. Revie. in Fish Biol. and Fisher., 13:379-407.

Jobling, M. (1994). Fish bioenergetics, Series, 13 published by Chapman and Hall-2-6 Boundary, R, London SBI 8HN, 300pp.

Kariman, A.S. (2009). Some observation on fisheries biology of Tilapia zillii (Gervais, 1884) and Solea vulgaris (Quensel,1806 in Lake Qarun, Egypt. World J. of Fish and Mar. Sci., 1:20-28.

Kaushik, S. J.; Coves, D.; Duttto, G. and Blanc, D. (2004). Almost total replacement of fish meal by plant protein sources in the diet of a marine teleost, the European sea bass, Dicentrarchus labrax. Aquacult., 230: 391-404.

Kissil, G.W.; Lupatsch, I.; Higgs, D. A. and Hardy, R. W. (2000). Dietary substitution of soy and rapeseed protein concentrates for fish meal, and their effects on growth and nutrient utilization in gilthead sea bream (Sparus aurata). Aquacult. Rese., 31: 595-601.

Knutsen, J.A. (1992). Feeding behavior of North sea turbot (Scophthalmus maxinus) and Dover sole (Solea solea) larvae elicited by chemical stimuli. Mar. Biol., 113: 543-548.

Lozano, N. B. S.; Vidal, A. T.; Martinez-Llorens, S.; Merida, S.N.; Blanco, J. E.; Lobez, A. M.; Torres, M. P. and Cerda, M. J. (2007). Growth and economic profit of gilthead sea bream (Sparus aurata L.) fed sunflower meal. Aquacult., 272: $\quad$ 528-534.

Mehanna, S. F. (2007). Stock assessment and management of the Egyption sole (Solea aegyptiaca Chabanaud, 1927, Osteichthyes: Soleidae) in the southeastern Mediterranean, Egypt. Turk. J. Zool., 31: 379-388.

Metailler, R.; Menu, B. and Moriniere, P. (1981). Weaning of Dover sole (Solea vulgaris) using artificial diets. J. world Maricul. Soc., 12: 111-116.

Metailler, R.; Cadena-Roa, M.. and Person-Le Ruyet, J. (1983). Attractive chemical substances for the weaning of Dover sole Solea vulgaris: qualitative and quantitative approach. J. World Maricult. Soc., 14: 674-584.

Osman, N. H.; Suriah, A. R. and Law, EC. (2001). Fatty acid composition and cholesterol content of selected marine fish in Malaysian water. Food Chem., 73: 55-60.

Passi, S.; Cataudella, S.; Dimarco, P.; De Simone, F. and Rastellii, L. (2002). Different Mediterranean species of fish and shellfish. J. Agr. Food Chem., 50: $7341-7322$.

Piccolo, G.; Morono, S.; Bovera, F.; Tudisco, R.; Caricato,G. and Nizzo, A. (2008). Effect of stocking density and protein/fat ratio of the diet on growth of Dover sole (Solea solea). Aquacult. Res., 39:1697-1704.

Rema, P.; Conceicao, L.E.C.; Evers, F.; Costro-Cunha, M.; Dinis, M.T. and Dias, J. (2008). Optimal dietary protein levels in Juvenile Senegalese sole (Solea senegalese). Aquacult. Nutr. ,14: 263-269.

SAS (1986). SAS User's Guide Version 6 Edition. SAS Institute,Cary,NC.USA.

Sabrah, M.M. (2004). Food and feeding habit of Solea solea from Bardawil lagoon, Egypt. International Conference Biological Science, 3: 1227-1248. 
Selmi, S.; Bouriga, N.; Cherif, M.; Toujami, H. and Trabelsi, M. (2010). Effect of drying process on biochemical and microbiological quality of silverside fish (Atherina lagunae). Internat. J. of Food Sci. and Technol., 45: 1161-1168.

Shantha, N.C. and Ackman, R.G. (1990). Nervoric acid versus tricosanoic acid as internal standards in quantitative gas chromatographic analyses of fish oil longer chain n-3 polyunsaturated fatty acid methyl esters. J.Chromatogr. 533:1-10.

Schluz, C.; Wickert, M.; Kijora, C.; Ogunji, J. and Rennert, B. (2007). Evaluation of pea protein isolate as alternative protein source in diets for juvenile tilapia (Oreochromis niloticus). Aquacult. Res., 38:537-545.

Silva, J.M.G.; Espe, M.; Conceicao, I.EC.; Dias, J. and Valente, L.MP. (2009). Senegalse sole juveniles (Solea senegalese Kaup,1858) grow equally well on diets devoid of fish meal provided the dietary amino acids are balanced. Aquacult., 296: 309-317.

Silva, J.M.G.; Espe, M.; Conceicao, I.EC.; Dias, J.; Costa, B. and Valente, L.MP. (2010). Feed intake and growth performance of Senegalese sole (Solea senegalese Kaup,1858) fed diets with partial replacement of fish meal with plant proteins. Aquacult. Nutrit., 41, e20-e30.

Snedecore, W.G. and Cochran, W.C.(1987). Statistical Methods. Iowa state Univ., USA.

Tacon, A.G.J (1995). Feed ingredients for carnivorous fish species: alternative to fish meal and other fishery resources, In:Reinertsen, H. Haaland,H. (Eds). Sustainable Fish Farming pp. 89-114.

Tacon, A.G.J. and Metian, M.(2008). Global overview on the use of fish meal and fish oil in industrially compounded aquafeeds: trends and future prospects. Aquacult., 285:146-158.

Valente, L. M. P.; Linares, F.; Villanueva, J. L. R.; Silva, J. M. G.; Espe, M.; Escorcio, C.; Pires, M. A.; Saaveedra, M. J.; Borges, P.; Medale, F.; AlvarezBlazquez, B. and Peleteiro, J. B. (2011). Dietary protein source or energy levels have no major impact on growth performance, nutrient utilization or flesh fatty acids composition of market-sized Senegalse sole. Aquacult., 318: 128-137.

Windsor, M. L. (2001). Fish meal. Department of trade and industry, Torry Research Station. Rep.No,49,FAO, http//www.fao.org./wairdocs/tan x5926e01htm.

Yones, A. M. and Abdel-Hakim, N. F. (2010). Dietary protein requirements for juvenile sole Solea aegyptiaca (Chabanaud, 1927). Egypt. J. Aquat. Biol. \& Fish., 15(1):71-87.

Zaboukas, Milliou, H.; Megalofonou, P. and Moraitou-Aposolopoulou, M. (2006). Chemical composition of Atlantic bonito Sarda sarda from the Aegean sea (eastern Mediterranean sea) in different stages of sexual maturity. J. Fish. Biol., 69: 347-362.

Zhang, Y.; Overland, M.; Xie,S.; Dong, Z.; Zhenming, L.V.; X. J. and Storebakken,T.(2012). Mixtures of lupin and pea protein concentrates can replace high-quality fish meal in extruded diets for juvenile black sea bream (Acanthopagrus schlegeli). Aquacult., 354-355: 68-74. 


\section{ARABIC SUMMARY}

\section{ادخال مسحوق البساريا لتحسين استساغة العليقة ومعدلات الأداء و التركيب الكيميائى لأ صبعيات أسماك موسنى.}

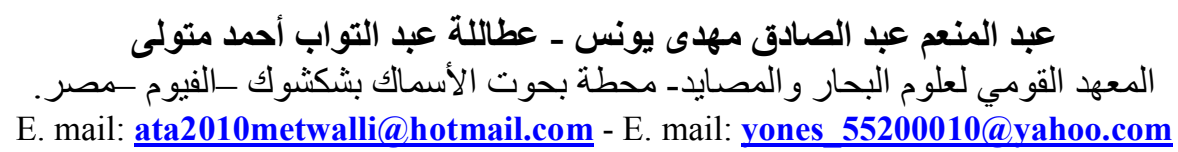

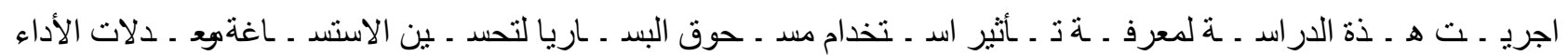

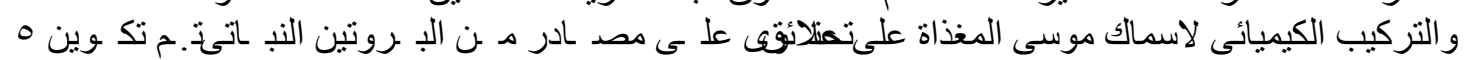

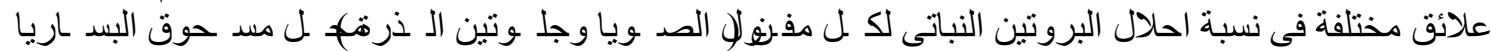

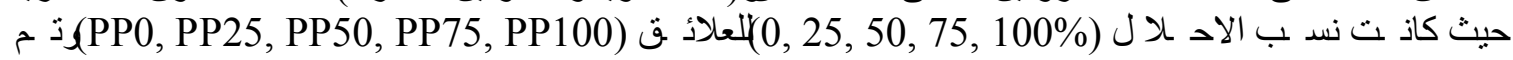

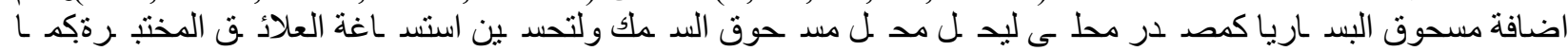

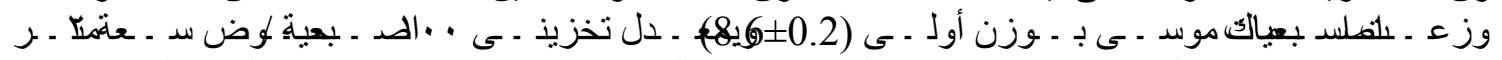

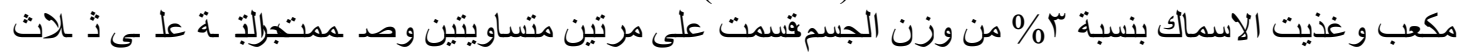

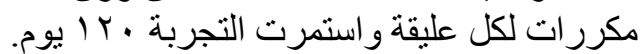

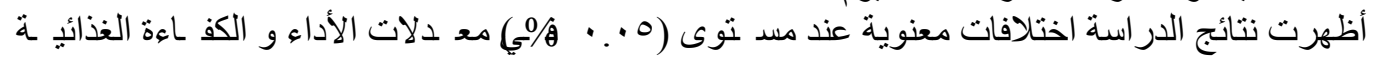

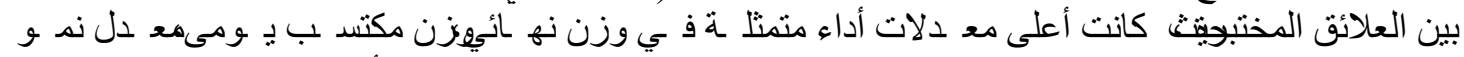

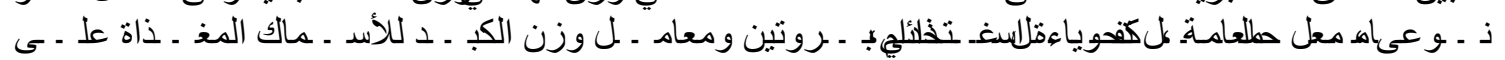

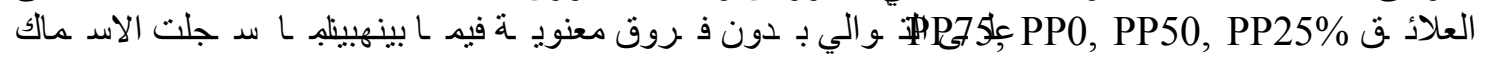

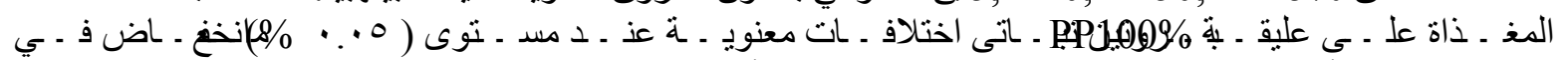

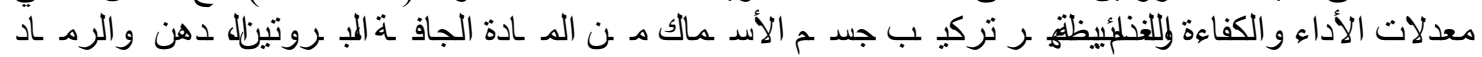

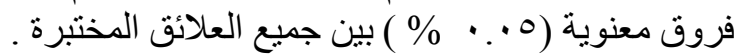

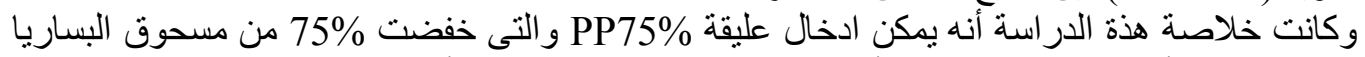

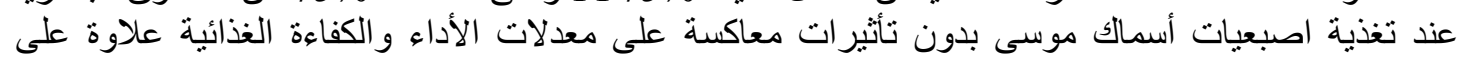
استخدام مصادر بروتين نباتية بديلة لتقليل نسبة استخدام مسحوق السمك مركئ مرتفع الثمن. 